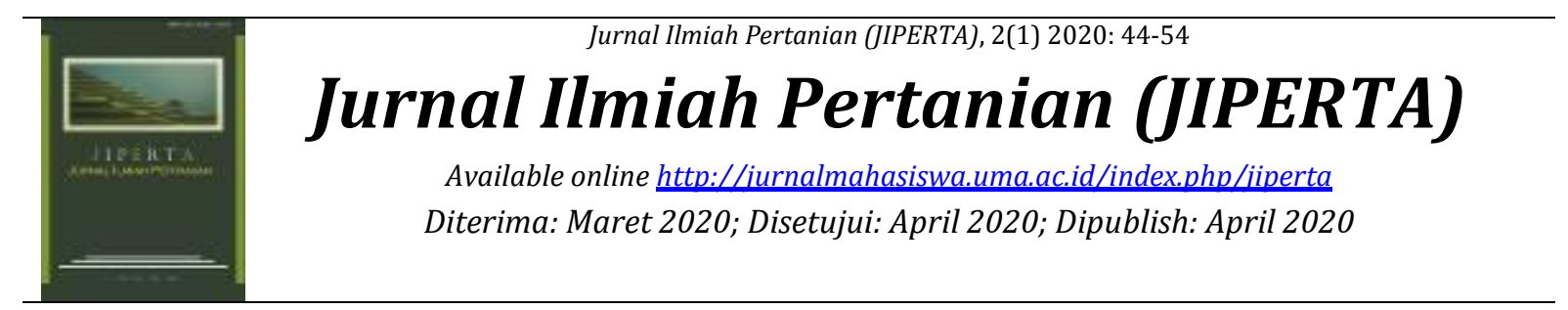

\title{
Respon Pertumbuhan, Produksi Dan Persentase Serangan Penyakit Pada Tanaman Bawang Merah (Allium Ascalonicum L.) Yang Di Beri 3 Jenis Kompos Kulit Buah Dan Poc Kubis
}

\section{Response of the growth, production and the percentage of attack of disease in onion plants that give 3 types of fruits skin compost and liquid organic fertilizer cabbage Roy Fernando'), Asmah Indrawati ${ }^{2)}$, Azwana ${ }^{1) *}$ \\ 1) Program Studi Agroteknologi, Fakultas Pertanian, Universitas Medan Area, Indonesia} \begin{abstract}
Abstrak
Bawang merah merupakan suatu kebutuhan pokok sehingga perlu peningkatan kunatitas produksi. Penelitian ini bertujuan untuk mengamati pengaruhs pemberian tiga jenis kompos kulit buah dan POC sawi terhadap pertumbuhan bawang merah. Metode yang digunakan dalam penelitian ini adalah metode Rancangan Acak Kelompok (RAK) Faktorial, yang terdiri dari 2 faktorperlakuan, yakni: 1) Pemberian pupuk kompos dan 2) Pemberian pupuk organik cair limbah kubis masing- masing perlakuan diulang sebanyak 2 (dua) kali. Parameter yang diamati dalam penelitian ini adalah tinggi tanaman (cm), jumlah daun (helai), jumlah umbi per tanaman sampel (buah), produksi per sampel (gr), produksi per plot (gr) dan persentase serangan penyakit tanaman. Adapun hasil yang diperoleh dari penelitian ini, yaitu : 1) Pemberian berbagai jenis kompos kulit buah berpengaruh tidak nyata terhadap tinggi tanaman, jumlah daun, jumlah umbi, produksi per tanaman sampel dan produksi per plot tanaman bawang merah; 2) Pemberian POC kubis berpengaruh tidak nyata terhadap tinggi tanaman, jumlah daun, jumlah umbi dan produksi per tanaman sampel, tetapi berpengaruh sangat nyata terhadap produksi per plot tanaman bawang merah; dan 3) Kombinasi antara kompos kulit buah dan Pupuk Organik Cair kubis berpengaruh tidak nyata terhadap tinggi tanaman, jumlah daun, jumlah umbi dan produksi per tanaman sampel, tetapi berpengaruh sangat nyata terhadap produksi per plot tanaman bawang merah.

Kata Kunci: bawang merah, kompos kulit buah dan POC kubis
\end{abstract}

\section{Abstract}

Onion is one of predominant flavor in Indonesia culinary which its quantity should be increased contantly. The aim of research was to invesitigate the respond of onion growth toward the treatment combination between POC cabbage and Tree types of fruit skin. This research was performed in a Factorial Randomized Block Design (RBD), which consists of 2 treatment factors, namely: 1) compost 2) liquid organic fertilizer of cabbage waste. The parameters observed in this study were plant height, number of leaves, number of tubers per sample plant, production per sample, production per plot and percentage of plant disease attack. As for the results obtained from this study, namely: 1) Giving various types of fruit skin compost did not significantly affect height, number of leaves, number of tubers, production per sample plant and production per plot of onion plants; 2) liquid organic fertilizer cabbage application has no significant effect on height, number of leaves, number of tubers and production per sample plant, but has a significant effect on production per plot of onion plant; and 3) Combination between the fruits compost and the liquid organic fertilizer that is not real influence on the plant height, the number of leaves, the number of bulbs and production per crop samples, but the effect is very real towards production per plot of the anion plants Keywords: onion plants, fruits skin compost and liquid organic fertilizer cabbage

How to Cite: Roy F, Asmah I, Azwana (2020). Respon Pertumbuhan, Produksi Dan Persentase Serangan Penyakit Pada Tanaman Bawang Merah (Allium Ascalonicum L.) Yang Di Beri 3 Jenis Kompos Kulit Buah Dan Poc Kubis. Jurnal Ilmiah Pertanian (JIPERTA), 2(1): 44-54

*E-mail: royfernando35@gmail.com ISSN 2550-1305 (Online)

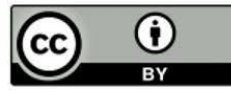




\section{PENDAHULUAN}

Bawang merah (Allium ascalonicum L.) merupakan salah satu kebutuhan pokok, namun kebutuhan bawang merah tidak dapat dihindari oleh konsumen rumah tangga sebagai pelengkap bumbu masakan sehari-hari (Lubis, 2017 ; Lawalata, 2017 ; Anitasari dkk., 2019 ; Ariyanti dkk., 2019 ; Novita dkk., 2019). Kegunaan lain dari bawang merah ialah sebagai obat tradisional yang manfaatnya sudah dirasakan oleh masyarakat luas. Demikian pula pesatnya pertumbuhan industri pengolahan makanan akhir- akhir ini juga cenderung meningkatkan kebutuhan bawang merah di dalamnegeri (Fimansyah dan Sumarni, 2013).

Bawang merah mengandung protein, lemak, karbohidrat, vitamin dan mineral, dan senyawa yang berfungsi sebagai anti-mutagen dan anti-karsinogen. Dari setiap 100 gram umbi bawang merah kandungan airnya mencapai 80-85 g, protein 1,5 g, lemak 0,3 g, karbohidrat 9,3 g. Adapun komponen lain adalah beta karoten $50 \mathrm{IU}$, tiamin $30 \mathrm{mg}$, riboflavin 0,04 mg, niasin $20 \mathrm{mg}$, asam askorbat (vitamin C) $9 \mathrm{mg}$. Mineralnya antara lain kalium $334 \mathrm{mg}$, zat besi $0,8 \mathrm{mg}$, fosfor $40 \mathrm{mg}$, dan menghasilkan energi 30 kalori (Tarmizi, 2010).

Pada dekade terakhir, kebutuhan bawang merah di Indonesia dari tahun ke tahun baik untuk konsumsi dan bibit dalam negeri mengalami peningkatan sebesar 5\%. Hal ini sejalan dengan bertambahnya jumlah penduduk yang setiap tahunnya juga mengalami peningkatan. Badan Pusat Statistik (BPS, 2016) menyatakan bahwa produksi bawang merah di Indonesia dari tahun 2011-2015 yaitu sebesar 893.124 ton, 964.195 ton, 1.010.773 ton, 1.233 .984 ton, 1.229 .184 ton. Pada tahun 2015 produksi bawang merah nasional mengalami penurunan dibandingkan tahun 2014 yaitu sebesar 0,39\%. Luas panen bawang merah di Indonesia tahun 2015 yaitu seluas $93.667 \mathrm{Ha}, 99.519 \mathrm{Ha}, 98.937$ Ha, $120.704 \mathrm{Ha}, 122.126 \mathrm{Ha}$. Luas panen nasional bawang merah tahun 2015 hanya mengalami pertumbuhan sebesar 1,18\% dibandingkan tahun 2014 (Festaria dkk., 2019 ; Misnun dkk., 2019 ; Setiawan dkk., 2019 ; Nurhijjah dkk., 2019).Dengan demikian, produktivitas dan mutu hasil bawang merah perlu ditingkatkan untuk memenuhi kebutuhan di dalam negeri(Dewi,2012).

Perkembangan pertanian organik di Indonesia dimulai pada awal 1980-an yang ditandai dengan bertambahnya luas lahan pertanian organik, dan jumlah produsen organik Indonesia dari tahun ke tahun. Berdasarkan data Statistik Pertanian Organik Indonesia (SPOI) yang diterbitkan oleh Aliansi Organis Indonesia (AOI) tahun 2009, diketahui bahwa luas total area pertanian organik di Indonesia tahun 2009 adalah 231.687,11 ha. Luas area tersebut meliputi luas lahan yang tersertifikasi, yaitu 97.351,60 ha (42 persen dari total luas area pertanian organik di Indonesia) dan luas lahan yang masih dalam proses sertifikasi (pilot project AOI), yaitu 132.764,85 ha 57 persen dari total luas area pertanian organic di Indonesia (Lingga, 2007).

Usaha yang dilakukan untuk memperbaiki kesuburan tanah adalah dengan melakukan pemupukan menggunakan pupuk organik. Kandungan unsur hara dalam pupuk kandang tidak terlalu tinggi, tetapi jenis pupuk ini mempunyai lain yaitu dapat memperbaiki sifat - sifat fisik tanah seperti permeabilitas tanah, porositas tanah, struktur tanah, daya menahan air dan kation - kation tanah. 
Roy Fernando, Asmah Indrawati \& Azwana, Respon Pertumbuhan, Produksi Dan Persentase Serangan Penyakit Pada Tanaman Bawang Merah (Allium Ascalonicum L.) Yang Di Beri 3 Jenis Kompos Kulit Buah Dan Poc Kubis

Pupuk organik cair adalah larutan dari hasil pembusukan bahan-bahan organik yang berasal dari sisa tanaman, kotoran hewan dan manusia yang kandungan unsur haranya lebih dari satu unsur. Kelebihan dari pupuk organik ini adalah mampu mengatasi defisiensi hara secara cepat, tidak bermasalah dalam dibandingkan dengan pupuk anorganik, pupuk organik cair umumnya tidak merusak tanah dan tanaman meskipun sudah digunakan sesering mungkin. Selain itu, pupuk ini juga memiliki bahan pengikat sehingga larutan pupuk yang diberikan ke permukaan tanah bisa langsung dimanfaatkan oleh tanaman. (Hadisuwito, 2012).

\section{METODE PENELITIAN Rancangan Penelitian}

Metode yang digunakan dalam penelitian ini adalah metode Rancangan Acak Kelompok (RAK) Faktorial, yang terdiri dari 2 faktor perlakuan, yakni (Sahputra dkk., 2019 ; Nubriama dkk., 2019):

1. Pemberian pupuk kompos (notasi K), terdiri dari 4taraf perlakuan, yakni :

$\mathrm{K} 0=$ Kontrol (Pupuk kandang sapi)

$\mathrm{K} 1$ = Kompos kulit kopi dengan dosis 10 ton $/ \mathrm{ha}\left(1 \mathrm{~kg} / \mathrm{m}^{2}\right)$

$\mathrm{K} 2=$ Kompos kulit durian dengan dosis 10 ton $/ \mathrm{ha}\left(1 \mathrm{~kg} / \mathrm{m}^{2}\right)$

$\mathrm{K} 3$ = Kompos kulit pisang kepok dengan dosis 10 ton $/ \mathrm{ha}\left(1 \mathrm{~kg} / \mathrm{m}^{2}\right)$

2. Pemberian pupuk organik cair limbah kubis (notasi $\mathrm{P}$ ), terdiri dari 4 taraf perlakuan, yakni :

$\mathrm{P} 0=$ kontrol (tanpa POC limbah kubis)

$\mathrm{P} 1=$ pemberian POC dengan dosis $1 \%$ atau setara dengan $10 \mathrm{ml} /$ liter air

P2 = pemberian POC dengan dosis $2 \%$ atau setara dengan $20 \mathrm{ml} /$ liter air

P3= pemberian POC dengan dosis $3 \%$ atau setara dengan $30 \mathrm{ml} /$ liter air

Pembuatan Pupuk Kulit Kopi, Durian dan Pisang

Bahan yang digunakan yaitu $8 \mathrm{~kg}$ kulit buah kopi, starbio EM41 L, gula merah $2 \mathrm{~kg}$, karung goni dan air 10 liter. Alat yang digunakan yaitu ember, gayung dan cangkul. Bahan komposberupa kulit buah kopi diletakkan di atas terpal, lalu disiram larutan EM4 yang tercampur dengan larutan gula merah dan di aduk hingga merata. Setelah itu ditutup dengan karung goni selama 21 hari untuk mempercepat dekomposisi. Setiap dua hari sekali dilakukan pengadukan ulang dan penambahan larutan EM4. Setelah terjadi dekomposisi selama 21 hari, maka pupuk kompos kulit buah kopi siap digunakan.

Bahan yang digunakan yaitu $8 \mathrm{~kg}$ kulit durian, EM41 L, gula merah $2 \mathrm{~kg}$, karung goni dan air 10 liter. Alat yang digunakan yaitu ember, gayung dan cangkul. Kulit durian dicacah kecil-kecil dandiletakkan di atas terpal, lalu disiram larutan EM4 yang tercampur dengan larutan gula merah dan diaduk hingga merata. Setelah itu ditutup dengan karung goni selama 21 hari untuk mempercepat dekomposisi. Setiap dua hari sekali dilakukan pengadukan ulang dan penambahan larutan EM4. Setelah terjadi dekomposisi selama 21 hari, maka pupuk kompos kulit durian siap digunakan.

$8 \mathrm{~kg}$ kulit pisang, starbio EM41 L, gula merah $2 \mathrm{~kg}$, karung goni dan air 10 liter. Alat yang digunakan yaitu ember, gayung dan cangkul. Kulit pisang kepong dincacah kecil- 
kecil dan diletakkan di atas terpal, lalu disiram larutan EM4 yang tercampur dengan larutan gula merah dan diaduk hingga merata. Setelah itu ditutup dengan karung goni selama 21 hari untuk mempercepat dekomposisi pada kompos kulit pisang. Setiap dua hari sekali dilakukan pengadukan ulang dan penambahan larutan EM4.Setelah terjadi dekomposisi selama 21 hari, maka pupuk kompos kulit pisang siap digunakan.

\section{Pembuatan Pupuk Kandang Sapi dan POC Kubis}

Bahan yang digunakan yaitu 8 kg pupuk kandang sapi, starbio EM41 L, gula merah $2 \mathrm{~kg}$, karung goni dan air 10 liter. Alat yang digunakan yaitu ember, gayung dan cangkul. Pupuk kandang sapi diletakkan di atas terpal, lalu disiram larutan EM4. limbah kubis sebanyak $10 \mathrm{~kg}$, gula merah 0,5 kg, EM4 sebanyak $50 \mathrm{ml}$ dan air secukupnya. Limbah kubis diletakkan di dalam ember. Setelah itu campur dengan larutan gula merah dan EM4 sebanyak $50 \mathrm{ml}$. Air secukupnya dan diaduk selama 15 menit. Kemudian difermentasikan selama 30 hari.

\section{Penanaman, Aplikasi, dan Pemeliharaan}

Sehari sebelum tanam, tanah bedengan/plot disiram secukupnya agar keadaan lapisan tanah atas cukup lembab. Sebelum itu kita terlebih dahulu melakukan pemotongan bagian ujung umbi kurang lebih setengah $\mathrm{cm}$,Setelah agak kering, dibuat guritan- guritan sejajar dengan lebar bedengan dan dalamnya $2-3 \mathrm{~cm}$, jarak tanam yang digunakan adalah $25 \mathrm{~cm} \times 25 \mathrm{~cm}$. Bibit dibenamkan dalam guritan dengan posisi tegak dan agak ditekan sedikit kebawah, kemudian ditutup dengan tanah tipis. Penanaman bawang merah yang terlalu dangkal menyebabkan tanaman mudah roboh, sebaliknya penanaman yang terlalu dalam akan menghambat pertumbuhan tunas karena tertutup oleh tanah. Aplikasi pupuk kompos kulit buah kopi, kulit durian dan kulit pisang dengan dosis yang sama yaitu $1 \mathrm{~kg} /$ plot yang diaplikasikan dengan cara menaburkan pada plot yang telah disiapkan 1 minggu sebelum tanam. Setelah itu, sampel dipelihara dan diamati. Parameter yang diamati meliputi pertumbuhan fegetatif dan produksi. Kemudian dianalisis dengan mengikuti kaidah statistic RAK Faktorial.

\section{HASIL DAN PEMBAHASAN}

Tinggi Tanaman (cm)

Rangkuman daftar sidik ragam respon pertumbuhan, produksi dan persentase serangan penyakit yang di beri 3 jenis kompos kulit buah dan poc kubis serta kombinasi kedua faktor perlakuan terhadap tinggi tanaman bawang merah disajikan pada Tabel 1.

Table 1. Rangkuman Daftar Sidik Ragam Respon Pertumbuhan, Produksi dan Persentase Serangan Penyakit yang di Beri 3 Jenis Kompos Kulit Buah dan POC Kubis serta Kombinasi Kedua Faktor Perlakuan Terhadap Tinggi Tanaman Bawang Merah

\begin{tabular}{|c|c|c|c|c|c|c|c|c|c|}
\hline \multirow{2}{*}{ SK } & \multicolumn{7}{|c|}{$\mathrm{F}_{\text {Hitung }}$} & \multicolumn{2}{|c|}{$\mathrm{F}_{\text {Tabel }}$} \\
\hline & 1 MST & 2 MST & 3 MST & 4 MST & 5 MST & 6 MST & 7 MST & $\mathrm{F}_{0,05}$ & $\mathrm{~F}_{0,01}$ \\
\hline $\mathrm{K}$ & $0,27 \mathrm{tn}$ & $1,27 \mathrm{tn}$ & $0,62 \mathrm{tn}$ & 0,72 th & $1,11 \mathrm{tn}$ & $0,32 \mathrm{tn}$ & 0,61 th & 3,29 & 5,42 \\
\hline $\mathrm{P}$ & $1,05 \mathrm{tn}$ & $0,02 \mathrm{tn}$ & $1,21 \mathrm{tn}$ & $0,83 \mathrm{tn}$ & $0,75 \mathrm{tn}$ & $1,09 \mathrm{tn}$ & $1,11 \mathrm{tn}$ & 3,29 & 5,42 \\
\hline $\mathrm{K} / \mathrm{P}$ & $1,09 \mathrm{tn}$ & $1,15 \mathrm{tn}$ & $1,15 \mathrm{tn}$ & $1,28 \mathrm{tn}$ & $1,29 \mathrm{tn}$ & $2,50 \mathrm{tn}$ & $1,84 \mathrm{tn}$ & 2,59 & 3,89 \\
\hline
\end{tabular}


Roy Fernando, Asmah Indrawati \& Azwana, Respon Pertumbuhan, Produksi Dan Persentase Serangan Penyakit Pada Tanaman Bawang Merah (Allium Ascalonicum L.) Yang Di Beri 3 Jenis Kompos Kulit Buah Dan Poc Kubis

Dari Tabel 1 dapat dilihat bahwa pemberian berbagai kompos dan POC kubis serta kombinasi kedua faktor perlakuan berpengaruh tidak nyata terhadap tinggi tanaman bawang merah.

Tidak nyatanya pemberian berbagai jenis kompos terhadap pertumbuhan dan produksi bawang merah juga dapat disebabkan karena dosis yang digunakan dalam penelitian ini diduga belum sesuai untuk mendukung pertumbuhan dan perkembangan tanaman. Kandungan hara dalam berbagai jenis kompos ini tergolong sudah cukup dan C/N-nya pun menjelaskan bahwa kompos sudah siap pakai. Tetapi dalam penelitian ini pemberian berbagai jenis kompos dilakukan hanya 1 kali, yakni sebanyak $1 \mathrm{~kg} / \mathrm{m} 2$ untuk kebutuhan 16 tanaman selama 3 bulan masa penelitian. Hal ini diperjelas dari hasil analisa tanah yang dilakukan di Laboratorium Pusat Penelitian Kelapa Sawit (2019), dimana diperoleh kandungan N 0,20\%; P 14,36 ppm; K 0,63 me/100 g dan pH 6,05.

Prihmantoro (1999) dalam Safei (2013) menjelaskan bahwa unsur hara N diperlukan tanaman untuk pertumbuhan vegetatif tanaman terutama batang, cabang dan daun.Kekurangan Nitrogen dapat mengakibatkantanaman tumbuh kerdil, sistem perakarannya terbatas, daun menjadi kuning atauhijau kekuningan dan cenderung cepat rontok.Nitrogen juga merupakan pengaturdari penggunaan Kalium, Fospor, dan penyusun lainnya. Pemberian Nitrogen yang berlebihan akanmenghambat kematangan, melunakkan tanaman, melemahkan tanaman terhadapserangan hama dan penyakit, serta mengurangi mutu hasil. Umumnyatanaman tergantung sepenuhnya dari Nitrogen terikat yang terdapat dalam larutantanah.Unsur nitrogen yang tersedia bagi tanaman sangat mudah hilang darilarutan tanah.

Jumlah Daun (helai)

Data pengamatan pengaruh pemberian berbagai jenis kompos dan POC kubis terhadap jumlah daun umur 1, 2, 3, 4, 5, 6 dan 7 MST. Rangkuman daftar sidik ragam respon pertumbuhan, produksi dan persentase serangan penyakit yang di beri 3 jenis kompos kulit buah dan poc kubis serta kombinasi kedua faktor perlakuan terhadap jumlah daun bawang merah dapat dilhat pada Tabel 2.

Table 2. Rangkuman Daftar Sidik Ragam Respon Pertumbuhan, Produksi dan Persentase Serangan Penyakit yang di Beri 3 Jenis Kompos Kulit Buah dan POC Kubis serta Kombinasi Kedua Faktor Perlakuan Terhadap Jumlah Daun Bawang Merah

\begin{tabular}{cccccccccc}
\hline \multirow{2}{*}{ SK } & \multicolumn{9}{c}{$\mathrm{F}_{\text {Hitung }}$} \\
\cline { 2 - 9 } & $1 \mathrm{MST}$ & $2 \mathrm{MST}$ & 3 MST & $4 \mathrm{MST}$ & $5 \mathrm{MST}$ & $6 \mathrm{MST}$ & $7 \mathrm{MST}$ & $\mathrm{F}_{0,05}$ & $\mathrm{~F}_{0,01}$ \\
\hline $\mathrm{K}$ & $0,35 \mathrm{tn}$ & $0,45 \mathrm{tn}$ & $1,24 \mathrm{tn}$ & $0,29 \mathrm{tn}$ & $0,35 \mathrm{tn}$ & $1,53 \mathrm{tn}$ & $0,19 \mathrm{tn}$ & 3,29 & 5,42 \\
$\mathrm{P}$ & $1,20 \mathrm{tn}$ & $1,55 \mathrm{tn}$ & $1,52 \mathrm{tn}$ & $0,56 \mathrm{tn}$ & $1,49 \mathrm{tn}$ & $1,00 \mathrm{tn}$ & $0,96 \mathrm{tn}$ & 3,29 & 5,42 \\
$\mathrm{~K} / \mathrm{P}$ & $0,48 \mathrm{tn}$ & $0,90 \mathrm{tn}$ & $0,75 \mathrm{tn}$ & $0,89 \mathrm{tn}$ & $2,43 \mathrm{tn}$ & $1,59 \mathrm{tn}$ & $0,99 \mathrm{tn}$ & 2,59 & 3,89 \\
\hline
\end{tabular}

Keterangan : $\mathrm{tn}=$ tidak nyata.

Dari Tabel 2 dapat dilihat bahwa pemberian berbagai kompos dan POC kubis serta kombinasi kedua faktor perlakuan berpengaruh tidak nyata terhadap jumlah daun bawang merah.

Pengaruh yang tidak nyata dari pemberian berbagai kompos diduga karena rendahnya unsur Nitrogen pada tanah, sehingga menghambat pertumbuhan dan perkembangan tanaman.Hal ini bisa dilihat dari hasil analisa tanah, dimana diperoleh 
bahwa kandungan Nitrogen pada tanah tergolong rendah. Walaupun penambahan berbagai bahan kompos dimaksudkan untuk menambah unsur hara pada tanah, tapi kenyataannya unsur hara yang terkandung di dalam kompos belum mampu untuk mendukung pertumbuhan tanaman. Hal ini sesuai dengan pendapat Lakitan (2007) dan Yuliarti (2007) dalam Aseptyo (2013) yang mengemukakan bahwa unsur hara yang berpengaruh terhadap pertumbuhan dan perkembangan daun adalah Nitrogen (N).Unsur Nitrogen $(\mathrm{N})$ berfungsi untuk merangsang pertunasan dan penambahan tinggi tanaman, selain itu nitrogen dalam jumlah yang cukup berperan dalam mempercepat pertumbuhan tanaman secara keseluruhan, khususnya batang dan daun. Selanjutnya Agustina (2000) dalam Rambe (2014) menjelaskan bahwa unsur N dan K merupakan unsur yang mudah tercuci, sehingga pemberian dalam bentuk NPK lebih tersedia bagi tanaman, sedangkan unsur $\mathrm{P}$ bersifat immobile.Oleh karena itu, unsur $\mathrm{N}$ dibutuhkan dalam jumlah yang banyak agar dapat memenuhi kebutuhan tanaman.

Jumlah Umbi per Tanaman Sampel (buah)

Sidik Ragam Respon Pertumbuhan, Produksi dan Persentase Serangan Penyakit yang di Beri 3 Jenis Kompos Kulit Buah dan POC Kubis serta Kombinasi Kedua Faktor Perlakuan Terhadap Jumlah Umbi per Tanaman Sampel diperlihatkan pada Tabel 3.

Table 3. Hasil Sidik Ragam Respon Pertumbuhan, Produksi dan Persentase Serangan Penyakit yang di Beri 3 Jenis Kompos Kulit Buah dan POC Kubis serta Kombinasi Kedua Faktor Perlakuan Terhadap Jumlah Umbi per Tanaman Sampel

\begin{tabular}{cccc}
\hline \multirow{2}{*}{$\mathrm{SK}$} & $\mathrm{F}_{\text {Hitung }}$ & \multicolumn{3}{c}{$\mathrm{F}_{\text {Tabel }}$} \\
\cline { 3 - 4 } & $2,06 \mathrm{tn}$ & $\mathrm{F}_{0,05}$ & $\mathrm{~F}_{0,01}$ \\
\hline $\mathrm{K}$ & $1,61 \mathrm{tn}$ & 3,29 & 5,42 \\
$\mathrm{P}$ & $2,46 \mathrm{tn}$ & 3,29 & 5,42 \\
$\mathrm{~K} \times \mathrm{P}$ & & 2,59 & 3,89 \\
\hline
\end{tabular}

Keterangan : $\mathrm{tn}=$ tidak nyata.

pemberian berbagai jenis kompos dan POC kubis serta kombinasi kedua faktor perlakuan berpengaruh tidak nyata. Tidak nyatanya pemberian berbagai jenis kompos terhadap jumlah umbi per sampel diduga karena tidak ada penambahan kompos selama penelitian. Pemberian kompos hanya dilakukan 1 kali saja selama penelitian (3 bulan), sementara dalam periode kurun waktu tersebut unsur hara yang terkandung di dalam kompos sudah digunakan untuk pertumbuhan tinggi tanaman dan jumlah daun.

Menurut Menzel, et al., (2003); Bhargava (2002) dan Wall (2010) dalam Thamrin, dkk. (2012), tanaman membutuhkan unsur hara dalam jumlah yang berbeda pada setiap kondisi dan fase pertumbuhannya. Ketersediaan hara pada periode tertentu berpengaruh positif pada hara tanaman buah dan produksi pada tahun berikutnya sebagai respon langsung terhadap kandungan hara tanah.

Hal ini juga didukung oleh Bagaskara (2011) dalam Sondakh, dkk., (2012)yang menyatakan bahwa unsur makro $\mathrm{N}, \mathrm{P}$, dan $\mathrm{K}$ mempunyai peranan masing-masing untuk tanaman diantaranya unsur nitrogen dibutuhkan untuk pertumbuhan daun dan pembentukan batang serta cabang. Unsur fosfor diperlukan bagi tanaman untuk perkembangan biji dan akar. Sementara unsur kalium berfungsi untuk membentuk bunga dan buah serta membantu tanaman melawan penyakit. 
Roy Fernando, Asmah Indrawati \& Azwana, Respon Pertumbuhan, Produksi Dan Persentase Serangan Penyakit Pada Tanaman Bawang Merah (Allium Ascalonicum L.) Yang Di Beri 3 Jenis Kompos Kulit Buah Dan Poc Kubis

\section{Produksi Basah per Sampel (g)}

Data pengamatan pengaruh pemberian berbagai jenis kompos dan POC kubis terhadap produksi per sampel dapat dilihat pada Lampiran 50. Sedangkan hasil analisa data secara statistik pada daftar sidik ragam dapat dilihat pada Tabel 4 .

Table 4. Hasil Sidik Ragam Respon Pertumbuhan, Produksi dan Persentase Serangan Penyakit yang di Beri 3 Jenis Kompos Kulit Buah dan POC Kubis serta Kombinasi Kedua Faktor Perlakuan Terhadap Produksi per Sampel

\begin{tabular}{cccc}
\hline \multirow{2}{*}{$\mathrm{SK}$} & \multirow{2}{*}{$\mathrm{F}_{\text {Hitung }}$} & \multicolumn{2}{c}{$\mathrm{F}_{\text {Tabel }}$} \\
\cline { 3 - 4 } & $0,15 \mathrm{tn}$ & $\mathrm{F}_{0,05}$ & $\mathrm{~F}_{0,01}$ \\
\hline $\mathrm{K}$ & $0,37 \mathrm{tn}$ & 3,29 & 5,42 \\
$\mathrm{P}$ & $0,57 \mathrm{tn}$ & 3,29 & 5,42 \\
$\mathrm{~K} x \mathrm{P}$ & 2,59 & 3,89 \\
\hline
\end{tabular}

Keterangan : $\operatorname{tn}=$ tidak nyata.

Dari Tabel 4 dapat dilihat bahwa pemberian berbagai jenis kompos dan POC kubis serta kombinasi kedua faktor perlakuan berpengaruh tidak nyata. Tidak nyatanya pemberian berbagai jenis kompos terhadap pertumbuhan dan produksi bawang merah juga dapat disebabkan karena dosis yang digunakan dalam penelitian ini belum sesuai untuk mendukung pertumbuhan dan perkembangan tanaman, dimana dalam hal ini dosis yang diberikan sebanyak $1 \mathrm{~kg} / \mathrm{m} 2$ untuk kebutuhan 16 tanaman selama 3 bulan.

Menurut Sutedjo dan Kartasapoetra (2002) dalam Mpapa (2016) bahwa unsur hara $\mathrm{N}$ berfungsi meningkatkan pertumbuhan tanaman; menyehatkan hijau daun (klorofil); meningkatkan kadar protein dalam tubuh tanaman; dan meningkatkan berkembangbiaknya mikro organisme dalam tanah yang penting bagi kelangsungan pelapukan bahan organik. Unsur $\mathrm{P}$ memiliki fungsi memacu dan memperkuat pertumbuhan tanaman dewasa; bahan pembentuk inti sel, berperan dalam pembelahan sel serta bagi perkembangan jaringan meristematik.Unsur $\mathrm{K}$ berfungsi mempercepat pembentukan zat karbohidrat dalam tanaman dan memperkokoh tubuh tanaman.

\section{Produksi Basah per Plot (g)}

pengaruh pemberian berbagai jenis kompos dan POC kubis terhadap produksi per plot dapat dilihat pada table 5 .

Table 5. Hasil Sidik Ragam Respon Pertumbuhan, Produksi dan Persentase Serangan Penyakit yang di Beri 3 Jenis Kompos Kulit Buah dan POC Kubis serta Kombinasi Kedua Faktor Perlakuan Terhadap Produksi per Plot

\begin{tabular}{cccc}
\hline \multirow{2}{*}{$\mathrm{SK}$} & $\mathrm{F}_{\text {Hitung }}$ & \multicolumn{2}{c}{$\mathrm{F}_{\text {Tabel }}$} \\
\cline { 3 - 4 } & 2,90 th & $\mathrm{F}_{0,05}$ & $\mathrm{~F}_{0,01}$ \\
\hline $\mathrm{K}$ & $15,84^{* * *}$ & 3,29 & 5,42 \\
$\mathrm{P}$ & $4,07 * *$ & 3,29 & 5,42 \\
$\mathrm{~K} \mathrm{x} \mathrm{P}$ & 2,59 & 3,89 \\
\hline
\end{tabular}

Keterangan $:$ tn $=$ tidak nyata; ${ }^{*}=$ nyata; ${ }^{* *}=$ sangat nyata.

Dari Tabel 5 dapat dilihat bahwa pemberian berbagai jenis kompos berpengaruh tidak nyata, sedangkan pemberian POC kubis serta interaksi kedua faktor perlakuan berpengaruh sangat nyata. Uji beda rataan secara Duncan's Test untuk faktor pemberian POC kubis dan kombinasi kedua faktor perlakuan dapat dilihat pada Tabel 6. 
Table 6. Beda Rataan Respon Pertumbuhan, Produksi dan Persentase Serangan Penyakit yang di Beri 3 Jenis Kompos Kulit Buah dan POC Kubis serta Kombinasi Kedua Faktor Perlakuan Terhadap Produksi per Plot

\begin{tabular}{cccc}
\hline Perlakuan & Rataan & $\alpha_{0,05}$ & $\alpha_{0,01}$ \\
\hline $\mathrm{P}_{0}$ & 228,75 & $\mathrm{bc}$ & $\mathrm{B}$ \\
$\mathrm{P}_{1}$ & 213,75 & $\mathrm{c}$ & $\mathrm{B}$ \\
$\mathrm{P}_{2}$ & 306,25 & $\mathrm{a}$ & $\mathrm{A}$ \\
$\mathrm{P}_{3}$ & 251,25 & $\mathrm{~b}$ & $\mathrm{~B}$ \\
\hline $\mathrm{K}_{0} \mathrm{P}_{0}$ & 230,00 & bcde & $\mathrm{BCD}$ \\
$\mathrm{K}_{0} \mathrm{P}_{1}$ & 195,00 & de & $\mathrm{CD}$ \\
$\mathrm{K}_{0} \mathrm{P}_{2}$ & 245,00 & bcd & $\mathrm{BCD}$ \\
$\mathrm{K}_{0} \mathrm{P}_{3}$ & 245,00 & bcd & $\mathrm{BCD}$ \\
\hline $\mathrm{K}_{1} \mathrm{P}_{0}$ & 165,00 & $\mathrm{e}$ & $\mathrm{D}$ \\
$\mathrm{K}_{1} \mathrm{P}_{1}$ & 210,00 & $\mathrm{cde}$ & $\mathrm{BCD}$ \\
$\mathrm{K}_{1} \mathrm{P}_{2}$ & 250,00 & bcd & $\mathrm{BCD}$ \\
$\mathrm{K}_{1} \mathrm{P}_{3}$ & 230,00 & bcde & $\mathrm{BCD}$ \\
$\mathrm{K}_{2} \mathrm{P}_{0}$ & 385,00 & $\mathrm{a}$ & $\mathrm{A}$ \\
$\mathrm{K}_{2} \mathrm{P}_{1}$ & 255,00 & bcd & $\mathrm{BCD}$ \\
$\mathrm{K}_{2} \mathrm{P}_{2}$ & 300,00 & $\mathrm{~b}$ & $\mathrm{AB}$ \\
$\mathrm{K}_{2} \mathrm{P}_{3}$ & 285,00 & $\mathrm{~b}$ & $\mathrm{BC}$ \\
$\mathrm{K}_{3} \mathrm{P}_{0}$ & 230,00 & bcde & $\mathrm{BCD}$ \\
$\mathrm{K}_{3} \mathrm{P}_{1}$ & 265,00 & bc & $\mathrm{BC}$ \\
$\mathrm{K}_{3} \mathrm{P}_{2}$ & 295,00 & $\mathrm{~b}$ & $\mathrm{AB}$ \\
$\mathrm{K}_{3} \mathrm{P}_{3}$ & 215,00 & cde & $\mathrm{BCD}$ \\
\hline \hline
\end{tabular}

Keterangan : Angka-angka yang diikuti notasi huruf yang berbeda pada satu kolom yang sama menunjukkan berbeda nyata pada taraf uji 0,05 (huruf kecil) dan berbeda sangat nyata pada taraf uji 0,01 (huruf besar).

Dari Tabel 6 dapat dilihat bahwa P2 berbeda sangat nyata terhadap P0, P1 dan P3 tetapi perlakuan P0 berbeda tidak nyata terhadap P1 dan P3.Sedangkan untuk kombinasi perlakuan diperoleh bahwa perlakuan K0P2 berbeda sangat nyata terhadap semua interaksi perlakuan lainnya.

bentuk kurva respon hubungan antara pemberian POC kubis dengan produksi per plot bawang merah adalah kwadratik positif, dengan persamaan : Y $=216+4,6 \mathrm{P}-0,1$ P2. Dari persamaan ini dapat pula dihitung konsentrasi maksimal dari POC kubis untuk menghasilkan produksi yang optimal adalah sebesar $23 \mathrm{ml} / \mathrm{l}$ air. Nilai koefisien determinasi ( $\mathrm{R} 2=0,3407$ ) menjelaskan bahwa pemberian POC kubis memberikan pengaruh sebesar $34,07 \%$ terhadap peningkatan produksi per plot bawang merah.

Tidak nyatanya pemberian berbagai jenis kompos terhadap pertumbuhan dan produksi bawang merah juga dapat disebabkan karena dosis yang digunakan dalam penelitian ini belum sesuai untuk mendukung pertumbuhan dan perkembangan tanaman, dimana dalam hal ini dosis yang diberikan sebanyak $1 \mathrm{~kg} / \mathrm{m} 2$ untuk kebutuhan 16 tanaman selama 2 bulan.

Pengaruh yang nyata dari pemberian POC limbah kubis erat kaitannya dengan unsur hara yang terkandung di dalam limbah kubis itu sendiri, dimana POC kubis mengandung unsur hara makro dan mikro yang sangat dibutuhkan untuk pertumbuhan dan perkembangan tanaman. Menurut Santi (2008) dalam Machrodania, dkk. (2015) dikatakan bahwa pupukorganik dalam bentuk cair memiliki kelebihandari pupuk organik dalam bentuk padat sepertilebih mudah diserap oleh tanaman karena unsur- 
Roy Fernando, Asmah Indrawati \& Azwana, Respon Pertumbuhan, Produksi Dan Persentase Serangan Penyakit Pada Tanaman Bawang Merah (Allium Ascalonicum L.) Yang Di Beri 3 Jenis Kompos Kulit Buah Dan Poc Kubis

unsuryang terdapat di dalamnya sudah teruraidan pengaplikasiannya lebih mudah. Selanjutnya Nurdin, dkk. (2009) dalamMachrodania, dkk. (2015) mengatakan bahwa adanya peningkatan proses fotosintesis akan meningkatkan pula hasil fotosintesis berupa senyawa-senyawa organik yang akan ditranslokasikan ke seluruh organ tanaman dan berpengaruh terhadap berat tanaman, dimana peningkatan proses fotosintesis dipengaruhi oleh unsur hara P.Jumini, dkk. (2011) dalam Puspadewi, dkk. (2014) mengatakan bahwa pemupukan dapatmeningkatkan pertumbuhan serta hasil panen secara kualitatif maupun kuantitatif. Menurut Rosmarkam dan Yuwono (2001)dalam Machrodania, dkk. (2015), pemberian unsurhara P meningkatkan pembentukan bunga, buahdan biji sehingga dapat meningkatkan hasilproduksi.

Jenis dan Persentase Serangan Penyaki

Selama penelitian ini berlangsung, melihat gejala yang ditimbulkan hanya ada 1 jenis penyakit yang menyerang tanaman bawang merah, yakni layu Fusarium yang menyerang tanaman menjelang panen, sehingga tidak sampai menimbulkan kegagalan panen (Gambar 1).Tingkat serangannya pun relatif kecil, yakni pada perlakuan K1P0 sebanyak 1 tanaman dan pada perlakuan K0P0 sebanyak 2 tanaman. Jika dihitung persentase serangannya pada K1P0 sebesar 6,25\% dan pada K0P0sebesar 12,5\%, relatif sangat kecil dan tidak signifikan di dalam mempengaruhi pertumbuhan dan produksi tanaman bawang merah.

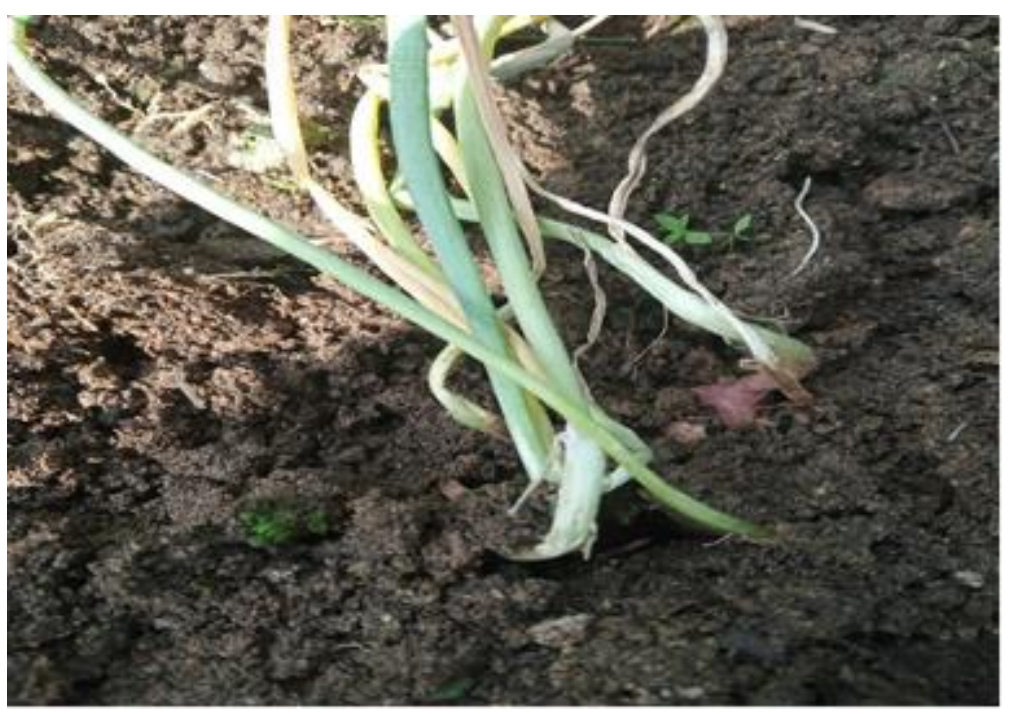

Gambar 1. Tanaman Terserang Penyakit Layu Fusarium

\section{SIMPULAN}

Berdasarkan penjabaran dari penelitian ini maka dapat disimpulkan bahwa pemberian 
berbagai jenis kompos kulit buah berpengaruh tidak nyata terhadap tinggi tanaman, jumlah daun, jumlah umbi, produksi per tanaman sampel dan produksi per plot tanaman bawang merah. Pemberian POC kubis berpengaruh tidak nyata terhadap tinggi tanaman, jumlah daun, jumlah umbi dan produksi per tanaman sampel, tetapi berpengaruh sangat nyata terhadap produksi per plot tanaman bawang merah. Kombinasi antara kompos kulit buah dan Pupuk Organik Cair kubis berpengaruh tidak nyata terhadap tinggi tanaman, jumlah daun, jumlah umbi dan produksi per tanaman sampel, tetapi berpengaruh sangat nyata terhadap produksi per plot tanaman bawang merah.

\section{DAFTAR PUSTAKA}

Anitasari, E., Prihastanti, E., \& Arianto, F. (2019). PENGARUH RADIASI PLASMA DAN PUPUK KANDANG KAMBING TERHADAP PERTUMBUHAN BAWANG MERAH VARIETAS BIMA BREBES. BIOLINK : Jurnal Biologi Lingkungan Industri Kesehatan, 6(2), 114-125. doi:https://doi.org/10.31289/biolink.v6i2.2639

Ariyanti, A., Prihastanti, E., \& Azam, M. (2019). RADIASI PLASMA PIJAR KORONA TERHADAP PERTUMBUHAN DAN KANDUNGAN NITROGEN TOTAL BAWANG MERAH DAN BAWANG BOMBAY. BIOLINK : Jurnal Biologi Lingkungan Industri Kesehatan, 6(2), 126-137. doi:https://doi.org/10.31289/biolink.v6i2.2693

Aseptyo FR. (2013). Pemanfaatan Ampas Tebu dan Ampas Teh Sebagai Media Tanam Terhadap Pertumbuhan Tanaman Cabai Merah Keriting (Capsicum annum L.) Ditinjau dari Intensitas Penyiraman Air Teh. Universitas Muhammadiyah Surakarta,

Dewi N. (2012). Aneka Bawang. In: Jogjakarta: Pustaka Baru Press.

Festaria, L., Ginting, R., \& Siregar, M. (2019). Analisis Produksi Jagung dengan Penyertaan Dana Penguatan Modal Lembaga Usaha Ekonomi Pedesaan (Dpm-Luep) di Provinsi Sumatera Utara. AGRISAINS: Jurnal Ilmiah Magister Agribisnis, 1(2), 138-145.

Firmansyah I, \& Sumarni N. (2016). Pengaruh dosis pupuk N dan varietas terhadap pH tanah, N-total tanah, serapan $\mathrm{N}$, dan hasil umbi bawang merah (Allium ascalonicum L.) pada tanah entisols-Brebes Jawa Tengah. Jurnal Hortikultura, 23(4), 358-364.

Hadisuwito S. (2012). Membuat pupuk organik cair: AgroMedia.

Lawalata, M. (2017). Risiko Usahatani Bawang Merah di Kabupaten Bantul. JURNAL AGRICA, 10(2), 56-73. doi:https://doi.org/10.31289/agrica.v10i2.924

Lingga P. (2001). Petunjuk penggunaan pupuk: Niaga Swadaya.

Lubis, R. (2017). UJI BEBERAPA VARIETAS DAN PEMBERIAN PUPUK BIOBOST TERHADAP PERTUMBUHAN DAN PRODUKSI BAWANG MERAH (Allium ascolonicum L.). BIOLINK : Jurnal Biologi Lingkungan Industri Kesehatan, 113-123. doi:https://doi.org/10.31289/biolink.v3i2.842

Machrodania Y, \& Ratnasari E. (2015). Pemanfaatan Pupuk Organik Cair Berbahan Baku Kulit Pisang, Kulit Telur dan Gracillaria gigas terhadap Pertumbuhan Tanaman Kedelai var Anjasmoro. Jurnal Lentera Bio. ISSN, 2252-3979.

Misnun, M., Hasnudi, H., \& Siregar, M. (2019). Analisis Pengaruh Perubahan Kebiasaan Makan Terhadap Kontinuitas Produksi Telur Itik Di Kabupaten Batu Bara. AGRISAINS: Jurnal Ilmiah Magister Agribisnis, 1(2), 146-151.

Mpapa BL. (2016). Analisis Kesuburan Tanah Tempat Tumbuh Pohon Jati (Tectona grandis L.) pada Ketinggian yang Berbeda. Jurnal Agrista, 20(3), 135-139.

Novita, D., Asaad, M., \& Rinanda, T. (2019). POTENSI DAN PELUANG PENGEMBANGAN SENTRA PRODUKSI BAWANG MERAH PROVINSI SUMATERA UTARA. JURNAL AGRICA, 12(2), 92-102. doi:https://doi.org/10.31289/agrica.v12i2.2870

Nubriama, R., Pane, E., \& Hutapea, S. (2019). pengaruh pemberian pupuk organik cair kandang kelinci dan kompos limbah baglog pada pertumbuhan bibit Kakao (theobroma cacao l.) Di polibeg. Jurnal Ilmiah Pertanian ( JIPERTA), 1(2), 143-152.

Nurhijjah, N., Kuswardhani, R., \& Kardhinata, E. (2019). Dampak Serangan Organisme Pengganggu Tanaman dan Perubahan Iklim terhadap Produksi dan Pendapatan Petani Padi Sawah di Sumatera Utara. AGRISAINS: Jurnal Ilmiah Magister Agribisnis, 1(1), 79-88.

Puspadewi S, Sutari W, \& Kusumiyati K. (2016). Pengaruh konsentrasi pupuk organik cair (POC) dan dosis pupuk N, P, K terhadap pertumbuhan dan hasil tanaman jagung manis (Zea mays L. var Rugosa Bonaf) kultivar talenta. Kultivasi, 15(3). 
Roy Fernando, Asmah Indrawati \& Azwana, Respon Pertumbuhan, Produksi Dan Persentase Serangan Penyakit Pada Tanaman Bawang Merah (Allium Ascalonicum L.) Yang Di Beri 3 Jenis Kompos Kulit Buah Dan Poc Kubis

Rambe, R.D.H. 2014. Pengaruh Pemberian Pupuk Organik dan Pupuk Anorganik Terhadap Pertumbuhan dan Produksi Jagung Manis (Zea mays saccharata L.). Wahana Inovasi Vol. 3 No.2 Juli-Des 2014.

Safei M, Rahmi A, \& Jannah N. (2014). Pengaruh jenis dan dosis pupuk organik terhadap pertumbuhan dan hasil tanaman terung (Solanum melongena L.) varietas Mustang F-1. Agrifor, 13(1), 59-66.

Sahputra, H., Suswati, S., \& Gusmeizal, G. (2019). Efektivitas aplikasi kompos kulit kopi dan Fungi mikoriza arbuskular terhadap produktivitas jagung manis. Jurnal Ilmiah Pertanian ( JIPERTA), 1(2), 102-112.

Setiawan, B., Sibuea, M., \& Pane, E. (2019). Analisis Faktor-Faktor yang Mempengaruhi Produksi Usahatani Nanas Pada Lahan Gambut di Kecamatan Panai Tengah Kabupaten Labuhanbatu. AGRISAINS: Jurnal Ilmiah Magister Agribisnis, 1(2), 100-108.

Sondakh TD, Joroh DN, Tulungen A, Sumampow D, Kapugu LB, \& Mamarimbing R. (2012). Hasil Kacang Tanah (Arachys hypogaea L.) Pada Beberapa Jenis Pupuk Organik. Eugenia, 18(1).

Suriadikarta, D.A. dan D. Setyorini. (2005). Laporan Hasil Penelitian Standar Mutu Pupuk Organik. Balai Penelitian Tanah. Bogor.

Suriani, N. (2011). Bawang Bawa Untung : Budidaya Bawang Merah dan Bawang Merah. Cahaya Atma Pustaka, Yogyakarta.

Tarmizi. (2010). Kandungan Bawang Merah dan Khasiatnya. UI. Jakarta

Thamrin M, Susanto S, Susila AD, \& Sutandi A. (2016). Hubungan Konsentrasi Hara Nitrogen, Fosfor, dan Kalium Daun Dengan Produksi Buah Sebelumnya Pada Tanaman Jeruk Pamelo. Jurnal Hortikultura, 23(3), 225-234. 